\title{
Strategi Komunikasi Krisis Dinas Pariwisata Provinsi Bali dalam Menghadapi Penyebaran Virus Korona
}

\author{
Putu Lingga Wacika \\ Program Studi Ilmu Komunikasi Universitas Telkom, Bandung, Indonesia \\ Contact: linggawacika2o@gmail.com
}

\begin{abstract}
Tourism is one of the sectors that is the mainstay of Bali Province. The spread of Corona Virus has an impact on many sectors, Bali's tourism is one of them. The Bali Provincial Tourism Office, as the government agency that oversees tourism, certainly carries out a communication strategy for the recovery of Bali's tourism. This research was conducted to find out how the crisis communication strategy of the Bali Provincial Tourism Office in dealing with the spread of the Corona Virus which has an impact on reducing tourism activities in Bali, as well as knowing what factors support and hinder the implementation of this communication strategy. The research method used is qualitative using a case study approach, and data collection is carried out by means of interviews, document collection, and observation. The results of this study indicate that the Bali Provincial Tourism Office implemented a communication strategy to carry out tourism activities in the new normal period by providing information on the situation and condition of Bali's tourism based on a predetermined phase. The Bali Provincial Tourism Office has partnered with all lines of the tourism sector to convey messages through online certification of health protocols and the formation of a communication team. The Love Bali website, social media, endorsers, and press conferences are used as media to inform the audience in an interactive way.
\end{abstract}

Keywords: Communication Strategy, Crisis, Corona Virus, Tourism

\begin{abstract}
ABSTRAK
Pariwisata merupakan salah satu sektor yang paling menjadi andalan Provinsi Bali. Penyebaran pandemi Virus Korona memberikan dampak bagi banyak sektor, salah satunya Pariwisata Bali. Dinas Pariwisata Provinsi Bali sebagi lembaga pemerintah yang menaungi pariwisata tentunya melakukan strategi komunikasi untuk pemulihan Pariwisata Bali. Penelitian ini dilaksanakan bertujuan untuk mengetahui bagaimana strategi komunikasi krisis Dinas Pariwisata Provinsi Bali dalam menghadapi penyebaran Virus Korona yang berdampak penurunan aktivitas pariwisata di Bali, serta mengetahui faktor apa saja yang mendukung dan menghambat pelaksanaan strategi komunikasi tersebut. Metode penelitian yang digunakan adalah kualitatif dengan menggunakan pendekatan studi kasus, serta pengumpulan data dilaksanakan dengan cara wawancara, pengumpulan dokumen, dan observasi. Hasil penelitian ini menunjukan bahwa Dinas Parwisata Provinsi Bali melakukan strategi komunikasi untuk melaksanakan aktivitas kepariwisataan pada masa new normal dengan cara memberikan informasi situasi dan kondisi Pariwisata Bali berdasarkan fase yang telah ditentukan. Dinas Pariwisata Provinsi Bali menjalin kemitraan dengan seluruh lini sektor pariwisata untuk menyampaikan pesan melalui sertifikasi online protokol kesehatan dan pembentukan tim komunikasi. Website Love Bali, media sosial, endorser, dan konferensi pers dijadikan sebagai media untuk menginformasikan pesan kepada audiens dengan cara yang interaktif.
\end{abstract}

Kata Kunci : Strategi Komunikasi, Krisis, Virus Korona, Pariwisata

\section{Pendahuluan}

Pada akhir 2019 China marak diperbincangkan akibat keberadaan Virus Korona. Virus Korona pertama kali terdeteksi di China pada 31 Desember di Kota Wuhan Provinsi Hubei China. Berdasarkan data yang dilansir dari disparda.baliprov.go.id pada Jumat, 31 Januari 2020 
pukul 11.00 WIB, China merupakan negara dengan penyumbang wisatawan terbesar bagi Bali. Dengan adanya wabah Virus Korona di China tentunya mengakibatkan penurunan kunjungan wisatawan di Bali.

Pada awal diketahui adanya wabah Virus Korona, Dinas Pariwisata Povinsi Bali sebagai badan pemerintah yang menaungi aktivitas pariwisata di Bali, menghimbau kepada seluruh pelaku industri pariwisata untuk tidak tergantung kepada China, kemudian Dinas Pariwisata Provinsi Bali juga melakukan beberapa komunikasi untuk menginformasikan bahwa sebagai destinasi pariwisata, Bali masih aman untuk dikunjungi. Situasi berubah total saat World Health Organization (WHO) mengumumkan status pandemi pada Virus Korona pada Rabu, 11 Maret 2020. Pada saat itu juga beberapa negara menerapkan kebijakan lock down, di mana warga negaranya tidak diperkenankan untuk keluar ataupun masuk dengan bebas. Menanggapi situasi tersebut Dinas Pariwisata Provinsi Bali menyatakan Pariwisata Bali ditutup sementara, segala bentuk komunikasi dilakukan untuk menginformasikan kepada wisatawan bahwa Pemerintahan Provinsi Bali sedang fokus menangani penyebaran Virus Korona. Berdasarkan hasil wawancara dengan Kepala Dinas Pariwisata Provinsi Bali, rencananya Bali akan kembali membuka pariwisata secara total pada tahun 2021 dengan menerapkan protokol kesehatan yang memadai.

Perkembangan yang terjadi pada Virus Korona tidak dapat diprediksi. Perubahan situasi terjadi sangat cepat dan di luar dugaan. Perubahan situasi yang dinamis tentunya sangat memengaruhi beberapa kebijakan, salah satunya strategi komunikasi yang diterapkan oleh Dinas Pariwisata Provinsi Bali. Middleton (dalam Cangara 2013:61) mengatakan bahwa strategi komunikasi adalah kombinasi terbaik dari semua elemen komunikasi (komunikator, pesan, media, komunikan, dan efek) dirancang guna mencapai tujuan komunikasi secara optimal. Pada awal diketahuinya Virus Korona, strategi komunikasi Dinas Pariwisata Provinsi Bali untuk mengomunikasikan bahwa Bali aman untuk dikunjungi, tetapi situasi berubah saat ditetapkannya status pandemi pada Virus Korona, Dinas Pariwisata Provinsi Bali mengomunikasikan bahwa pihaknya dan seluruh jajaran Pemerintah Provinsi Bali fokus untuk mengatasi penyebaran Virus Korona di Bali sehingga pariwisata di tutup sementara, hingga rencana akan dibukanya kembali Pariwisata Bali dengan menerapkan protokol kesehatan. Berdasarkan latar belakang yang telah dipaparkan sebelumnya, peneliti sangat tertarik untuk mengetahui Strategi Komunikasi Krisis Dinas Pariwisata Provinsi Bali Dalam Menghadapi Penyebaran Virus Korona Yang Berdampak Penurunan Aktivitas Pariwisata Di Bali.

Marthin dan Anderson (dalam Cangara, 2013:64) menyatakan pandangannya bahwa strategi merupakan suatu seni dalam berfikir untuk mengoptimalkan seluruh sumber daya yang dimiliki untuk dapat mencapai tujuan yang telah ditetapkan secara maksimal.

Horald D Lasswell (dalam Tatang, 2016:85) Mengatakan, strategi komunikasi dapat dikatakan efektif jika mampu memjawab pertanyaan "Who Says What in Which Channel to Whom With What Effect?"

a. Who (Komunikator): Komunikator merupakan seseorang yang berperan sebagai pembuat pesan dan secara bersamaan berperan sebagai sumber dari suatu informasi dari segala kondisi baik secara tidak disengaja maupun disengaja. 
b. Says What (Pesan): Pesan merupakan sesuatu hal yang dikirimkan baik langsung maupun tidak langsung. Pesan yang disampaikan dapat berupa verbal ataupun nonverbal.

c. In Which Channel (Media yang digunakan): Media merupakan suatu alat yang berperan sebagai perantara pesan pesan yang disampaikan oleh komunikator kepada komunikan.

d. To Whom (Komunikan): Komunikan merupakan kelompok atau individu tertentu yang menjadi target sasaran pesan yang disampaikan oleh komunikator, yang berperan sebagai penerima pesan dalam proses komunikasi.

e. With What Effect (Efek): Efek merupakan reaksi, tanggapan, ataupun respons komunikasi disaat seseorang menerima pesan dari pembuat pesan, dengan kata lain efek merupakan akibat dari aktivitas komunikasi.

Krisis merupakan suatu peristiwa yang dapat terjadi pada setiap individu ataupun organisasi dalam menjalankannya, baik secara makro maupun mikro. Krisis yang dialami, akan berpotensi menimbulkan dampak negatif bagi sebuah perusahaan jika tidak mampu dikelola dengan baik. G. Harrison, (dalam Kriyantono, 2015:198) memberikan definisi bahwa krisis adalah suatu kondisi yang kritis berhubungan dengan sebuah peristiwa yang berpotensi memberikan pengaruh negatif terhadap organisasi.

Dalam mengatasi suatu situasi krisis, komunikasi merupakan sesuatu hal yang sangat penting untuk diterapkan oleh suatu organisasi. G Harrison (dalam Kriyantono, 2015:201), mendefinisikan bahwa komunikasi krisis merupakan upaya yang dilaksanakan oleh organisasi dalam membuka saluran komunikasi dan memberikan pesan-pesan yang relevan yang berkaitan dengan situasi krisis.

Bungin (2015:92), mendifinisikan bahwa komunikasi pariwisata pada perkembangannya dapat menyatukan banyak disiplin ilmu dalam suatu kajian yang berkaitan dengan komunikasi dan pariwisata. IImu komunikasi pariwisata mempunyai relasi secara biologis dengan ilmu komunikasi dan pariwisata. Komunikasi mengeluarkan teori komunikasi massa, kelompok, interpersonal, dan persuasive, kemudian pariwisata mengeluarkan kajian destinasi pariwisata, aksesibilitas destinasi, kelembagaan pariwisata, sumber daya manusia, dan pemasaran pariwisata.

\section{Metode}

Penelitian ini menggunakan metode penelitian kualitatif. Taylor dan Bodgan (dalam Ahmadi, 2014:15), mendefinisikan bahwa metode kualitatif adalah prosedur penelitian yang menghasilkan data dalam bentuk lisan atau kata-kata dan tingkah laku yang bisa diamati dari suatu subjek. Penelitian ini dilaksanakan di Kantor Dinas Pariwisata Provinsi Bali yang berlokasi di Jala S. Parman, Niti Mandala Renon. Data yang didapatkan berasal dari catatan wawancara, catatan lapangan, dokumen pribadi, foto, video, dan dokumen lainnya. Metode kualitatif digunakan dalam penelitian ini untuk menganalisis keadaan yang terjadi sebenarnya dan sesuai berdasarkan situasi saat penelitian dilaksanakan tanpa memanipulasinya. Dalam penelitian ini, peneliti berperan sebagai alat penelitian secara konsisten serta hasil dari penelitian yang diperoleh langsung dari wawancara mendalam dan observasi. Penelitian ini menggunakan 
pendekatan penelitian studi kasus. Pendekatan studi kasus merupakan metode riset yang memakai sumber data sebanyak-banyaknya yang mampu digunakan untuk meneliti, menguraikan, dan memberi penjelasan menyeluruh mengenai aspek kelompok, individu, peristiwa, atau organisasi dengan cara yang sistematis (Kriyantono, 2006:65).

\section{Hasil dan Pembahasan}

\section{Perencanaan}

Marthin dan Anderson (dalam Cangara, 2013:64) menyatakan pandangannya bahwa strategi merupakan suatu seni dalam berfikir untuk mengoptimalkan seluruh sumber daya yang dimiliki untuk dapat mencapai tujuan yang telah ditetapkan secara maksimal. Maka dari itu, sebelum organisasi menjalankan strategi komunikasi secara optimal, haruslah menentukan tujuan komunikasinya. Berdasarkan hasil wawancara, tujuan komunikasi dari Dinas Pariwisata Provinsi Bali dalam hal ini adalah untuk menginformasikan kepada wisatawan maupun calon wisatawan yang akan berkunjung ke Bali mengenai kondisi dan situasi perkembangan Pariwisata Bali pada masa pandemi Virus Korona berdasarkan fase yang telah ditentukan.

Harrison (dalam Kriyantono, 2015:201), mendefinisikan bahwa komunikasi krisis merupakan upaya yang dilaksanakan oleh organisasi dalam membuka saluran komunikasi dan memberikan pesan-pesan relevan yang berkaitan dengan situasi krisis. Dalam hal ini, Dinas Pariwisata Provinsi Bali melaksanakan komunikasi krisis untuk memberikan pesan kepada wisatawan ataupun calon wisatawan mengenai situasi dan kondisi Bali secara intensif.

\section{Strategi Perancangan Pesan}

a. Konten Pesan: Berdasarkan hasil wawancara, peneliti memahami bahwa isi konten pesan yang dirancang mengandung unsur informatif dan tepat sasaran.

Informatif: Konten pesan yang dirancang oleh Dinas Pariwisata Provinsi Bali mengandung unsur informatif yang bertujuan untuk menginformasikan wisatawan ataupun calon wisatawan mengenai situasi dan kondisi perkembangan Pariwisata Bali pada masa pandemi Virus Korona. Pesan informatif yang diberikan oleh Dinas Pariwisata Provinsi Bali, meliputi:

1. Fase satu saat Virus Korona belum ditetapkan sebagai pandemi, Dinas Pariwisata Provinsi Bali menginformasikan bahwa Bali masih aman untuk dikunjungi.

2. Fase dua saat Virus Korona sudah ditetapkan sebagai pandemi, Dinas Pariwisata Provinsi Bali menginformasikan bahwa wisatawan dilarang sementara untuk berkunjung, karena Bali sedang fokus menangani pandemi Virus Korona.

3. Fase tiga saat adaptasi kebiasaan baru, Dinas Pariwisata Provinsi Bali menginformasikan bahwa wisatawan yang akan berlibur ke Bali wajib melaksanakan protokol kesehatan yang sudah ditetapkan.

Tepat Sasaran: Seluruh wisatawan ataupun calon wisatawan yang akan berlibur ke Bali harus memahami persyaratan khusus untuk dapat berlibur dengan menerapkan protokol kesehatan yang telah ditentukan. 
b. Strategi Penyampaian Pesan Melalui Medium

\section{Interaktif}

Berdasarkan hasil wawancara peneliti dengan informan kunci, Dinas Pariwisata Provinsi Bali menggunakan media yang mampu menyampaikan konten pesan informatif dengan cara yang interaktif, sehingga pesan yang disampaikan dapat dipahami dan diimplementasikan dengan baik dan benar. Dalam aktivitasnya, terdapat beberapa indikator Dinas Pariwisata Provinsi Bali dalam penyampaian pesan melalui medium, yaitu:

\section{a. Anggaran}

Berdasarkan hasil wawancara, terdapat dua sumber anggaran dalam penyampaian pesan melalui medium. Jika kontennya mengarah kepada aktivitas penanganan pandemi secara umum, maka anggaran langsung dikeluarkan Pemerintah Provinsi Bali melalui Dinas Komunikasi dan Informatika Provinsi Bali. Jika kontennya mengarah kepada aktivitas pengembangan dan pemulihan pariwisata selama pandemi, maka anggaran dikeluarkan Dinas Pariwisata Provinsi Bali.

b. Jangkauan Audiens

Berdasarkan hasil wawancara dengan informan kunci, peneliti memahami bahwa dalam menggunakan media, Dinas Pariwisata Provinsi Bali lebih mengandalkan media dengan frekuensi pengguna yang tinggi, seperti facebook, whatsapp, dan email. Hal ini dikarenakan media tersebut dapat menyebarkan informasi dengan cepat dan audiens dapat melakukan percakapan langsung dengan pihak Dinas Pariwisata Provinsi Bali. Saat ini, Dinas Pariwisata Pariwisata Provinsi Bali sedang gencar membuat website yang diharapkan mampu memudahkan monitoring pariwisata di era new normal.

\section{c. Tren Wisatawan}

Dalam melaksanakan pemilihan media, Dinas Pariwisata Provinsi Bali menyesuaikan berdasarkan tren wisatawan. Media yang dipilih disesuaikan berdasarkan media yang paling banyak dan paling mudah digunakan oleh wisatawan, sehingga memungkinkan untuk terjadinya interaksi dengan wisatawan atau calon wisatawan.

\section{Pelaksanaan}

\section{a. Kemitraan}

Dalam menjalankan strategi komunikasi krisis, Dinas Pariwisata Provinsi Bali sebagai institusi pemerintah yang menaungi sektor pariwisata di Bali tidak bisa melaksanakan aktivitasnya sendiri. Dinas Pariwisata Provinsi Bali melibatkan pemangku kepentingan di seluruh lini sektor pariwisata, seperti hotel, restoran, travel agent, transportasi, objek wisata, dan lainnya.

\section{Sertifikasi Protokol Kesehatan}

Berdasarkan hasil wawancara, bentuk kemitraan yang dilaksanakan adalah pembuatan sertifikasi protokol kesehatan secara online bahwa pemangku kepentingan di seluruh lini sektor pariwisata tersebut siap beroperasi di masa new normal dengan menerapkan standar protokol kesehatan yang telah ditetapkan. Pembuatan sertifikasi ini diharapkan 
mampu menciptakan rasa aman bagi wisatawan ataupun calon wisatawan yang akan berlibur ke Bali.

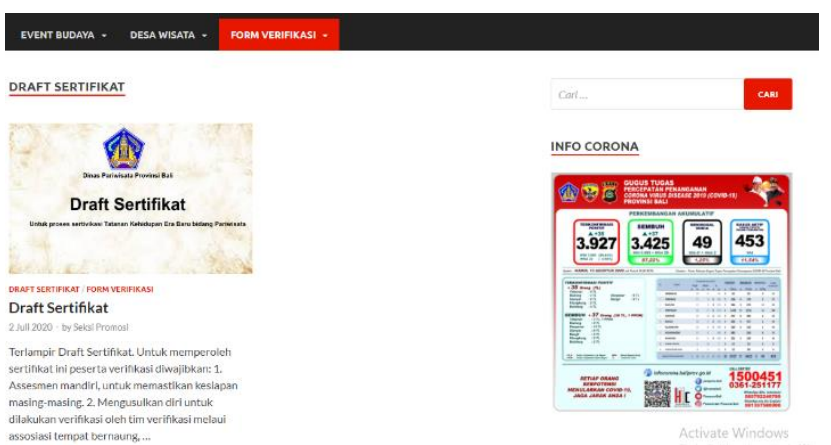

Gambar 1. Sertifikasi Online Pariwisata Bali

Sumber: https://disparda.baliprov.go.id/ diakses pada Senin, 7 September 2020 pukul 20.01 WITA

\section{Tim Komunikasi}

Tim komunikasi krisis dibentuk antar lintas bidang dan melibatkan pakar dari luar yang memiliki kredibilitas baik dalam menangani krisis. Tim komunikasi krisis yang telah dibentuk kemudian diberikan pembagian kerja yang baik untuk mencapai tujuan dari organisasi. (Kriyantono, 2015: 246-259). Berdasarkan skalanya, Dinas Pariwisata Provinsi Bali memiliki dua tim komunikasi, yaitu secara internal dan eksternal.

1. Tim We Love Bali Movement

Berdasarkan hasil wawancara, dalam mengumpulkan fakta-fakta terkait situasi dan kondisi pariwisata di Bali, secara internal Dinas Pariwisata Provinsi Bali membentuk tim komunikasi, yaitu We Love Bali Movement. Tim ini beranggotakan internal Dinas Pariwisata Provinsi Bali sendiri dibantu dengan relawan dari pelaku industri pariwisata di Bali yang tentunya memiliki pengalaman di bidang pariwisata. Tim komunikasi ini juga berinteraksi secara langsung dengan audiens melalui pemberitaan situasi dan kondisi secara nyata di lapangan.

2. Gugus Tugas Covid 19

Berdasarkan hasil wawancara, dalam menghadapi penyebaran Virus Korona, secara eksternal Dinas Pariwisata Provinsi Bali bekerja sama dengan seluruh jajaran yang ada di Pemerintahan Provinsi Bali dalam membentuk Satgas Penanganan Virus Korona yang dipimpin langsung oleh Sekretaris Daerah Provinsi Bali. Dalam Satgas tersebut Dinas Pariwisata Provinsi Bali bertugas untuk memonitoring dan memberikan informasi terkait aktivitas kepariwisataan yang ada di Bali. Tim komunikasi ini juga membuka saluran komunikasi interaktif terkait penanganan Virus Korona melalui layanan pengaduan langsung.

\section{b. Penggunaan Media}

\section{Media Sosial}

Dinas Pariwisata Provinsi Bali menggunakan media sosial (facebook, instagram, twitter, whatsapp, dan email) dalam menyampaikan pesan terkait situasi dan kondisi pariwisata di Bali berdasarkan fase yang telah digunakan. Media sosial tersebut dipilih karena 
memungkinkan interaksi dengan cepat, sehingga pesan-pesan yang telah disampaikan dapat direspons dengan baik oleh audiens.

Tabel 1.

Media Sosial Dinas Pariwisata Provinsi Bali

Instagram Dinas Pariwisata Provinsi Bali
Agustus 2020 pukul 22.00 WITA
Sumber:
https://www.facebook.com/103205031221950?referrer=whatsa
pp diakses pada 19 Agustus 2020 pukul 22.01 WITA

Sumber: Olahan Peneliti, Agustus 2020

\section{Website Love Bali}

Berdasarkan hasil wawancara, salah satu strategi komunikasi yang dilaksanakan oleh Dinas Pariwisata Provinsi Bali dalam menyampaikan pesan yang informatif melalui media yang interaktif kepada audiens mengenai situasi dan kondisi pariwisata di Bali selama masa pandemi adalah melalui website Love Bali. Pada website tersebut terdapat beberapa artikel berita yang akan menginformasikan audiens situasi dan kondisi terkini pariwisata di Bali. Hal yang terpenting pada website ini adalah semua wisatawan yang akan melaksanakan aktivitas kepariwisataan di Bali diwajibkan untuk mendata diri. Aktivitas pendataan diri tersebut bertujuan agar pihak Dinas Pariwisata Provinsi Bali mampu mengetahui data-data, seperti riwayat asal, tujuan destinasi, dan waktu tinggal wisatawan selama melaksanakan aktivitas kepariwisataan di Bali. Pada website ini, wisatawan juga dapat berpartisipasi dalam pembangunan Pariwisata Bali melalui donasi, karena sesuai dengan program dari Pemerintah 
Provinsi Bali untuk kedepannya Bali akan lebih menekankan pariwisata berbasis alam dan budaya, sehingga alam dan budaya Bali tetap ajeg dan lestari.

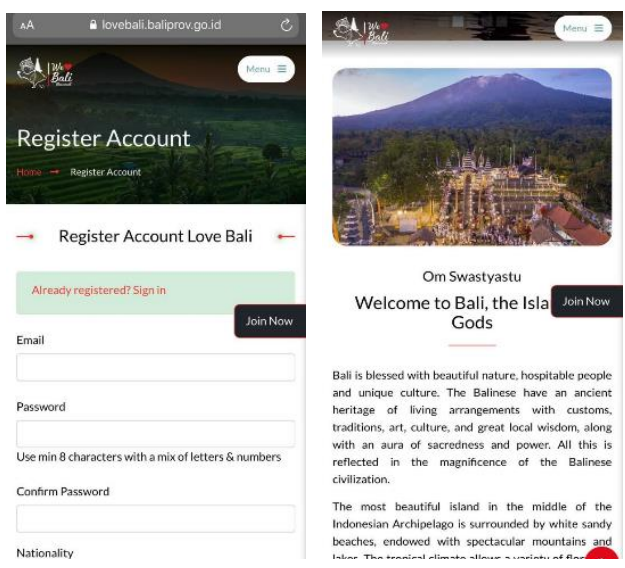

Gambar 2. Website We Love Bali

Sumber: http://lovebali.baliprov.go.id/ diakses pada Senin, 7 September 2020 pukul 09.30 WITA

\section{Endorser}

Dinas Pariwisata Provinsi Bali juga memanfaatkan endorser untuk menyampaikan pesan strategi komunikasinya. Berdasarkan hasil wawancara peneliti dengan informan kunci, dalam menyampaikan pesan kepada audiens, Dinas Pariwisata Provinsi Bali juga menggunakan public figure yang tentunya memiliki kredibilitas dalam menyampaikan pesan. Public figure yang digunakan berasal dari kalangan artist dan para pemimpin di Pemerintahan, seperti Gubernur dan Wakil Gubernur Bali, Menteri Pariwisata dan Ekonomi Kreatif, dan sebagainya.

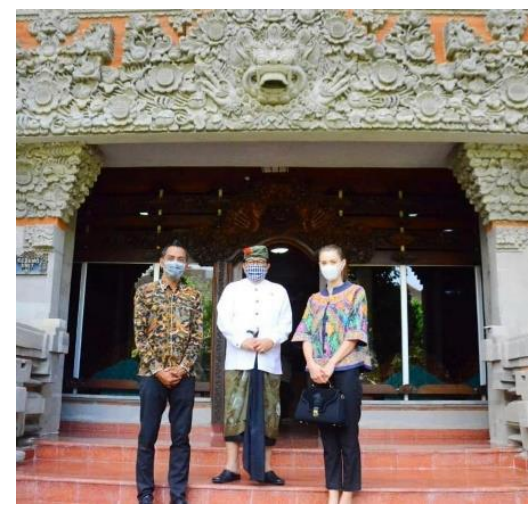

Gambar 3. Pertemuan Pemerintah Provinsi Bali dengan Tina Bule Sebagai Influencer Dalam Rangka Pembuatan Konten Promosi Pariwisata

Sumber: Instagram @pemprov_bali diakses pada

Kamis, 27 Agustus 2020 pukul 13.29 WITA)

\section{Konferensi Pers}

Salah satu strategi komunikasi dari Dinas Pariwisata Provinsi Bali adalah melaksanakan konferensi pers secara berkala. Tujuan dari dilaksanakannya konferensi pers secara berkala untuk memberikan informasi-informasi ataupun fakta-fakta terbaru terkait terjadinya suatu krisis, sehingga tidak memunculkan pandangan buruk publik terhadap suatu organisasi. Teknis 
pelaksanaan konferensi pers dari Dinas Pariwisata Provinsi Bali disesuaikan dengan situasi, kondisi, dan kebutuhan. Tempat konferensi pers bisa dilakukan di ruangan Kepala Dinas Provinsi Bali, semua wartawan dikumpulkan dan diberi penjelasan dan bisa dilakukan jarak jauh melalui telefon.

\section{Evaluasi}

Menurut Cangara (2013:48), evaluasi adalah suatu cara yang mampu digunakan untuk menilai kesuksesan aktivitas komunikasi yang telah dilakukan yang bertujuan untuk melaksanakan perbaikan dan meningkatkan keberhasilan yang diraih sebelumnya. Dinas Pariwisata Provinsi Bali melaksanakan evaluasi secara internal dan eksternal.

a. Evaluasi Internal

Berdasarkan hasil wawancara, pelaksanaan evaluasi internal Dinas Pariwisata Provinsi Bali dilaksanakan dengan cara memerikasa fungsi dari setiap departemen internal yang ada di dalam Dinas Pariwisata Provinsi Bali. Pemeriksaan fungsi ini dilaksanakan untuk mengetahui seberapa efektif program kerja yang dilaksanakan dalam menangani penyebaran Virus Korona yang berdampak penurunan aktivitas pariwisata Provinsi Bali, seperti bagian promosi yang saat ini sudah tidak lagi membuat konten Bali aman untuk dikunjungi, tetapi membuat konten kalau Bali sudah siap menangani Virus Korona.

b. Evaluasi Eksternal

Berdasarkan hasil wawancara dengan informan kunci, pelaksanaan evaluasi eksternal Dinas Pariwisata Provinsi Bali dilaksanakan melalui beberapa cara, antara lain:

\section{Verifikasi Protokol Kesehatan}

Berdasarkan hasil wawancara, pelaksanaan evaluasi eksternal Dinas Pariwisata Provinsi Bali dilaksanakan melalui pemeriksaan langsung ke seluruh lini sektor pariwisata mengenai pelaksanaan protokol kesehatan. Pemeriksaan ini bertujuan untuk mengevaluasi seberapa efektif program persiapan yang telah dilakukan Dinas Pariwisata Provinsi Bali untuk pemulihan pariwisata di era new normal. Hasil dari verifikasi ini akan dijadikan acuan dalam pembuatan program selanjutnya.

Koordinasi dengan Duta Besar Negara Penyumbang Wisatawan

Mengkaji aktivitas komunikasi melalui koordinasi yang dijalin antara Dinas Pariwisata Provinsi Bali dengan negara-negara yang menjadi penyumbang wisatawan bagi Bali. Koordinasi ini bertujuan untuk mengetahui negara mana yang masuk daftar zona merah, sehinga pihak Dinas Pariwisata Provinsi Bali dapat mengambil tindakan agar aktivitas kepariwisataan di Bali aman. 


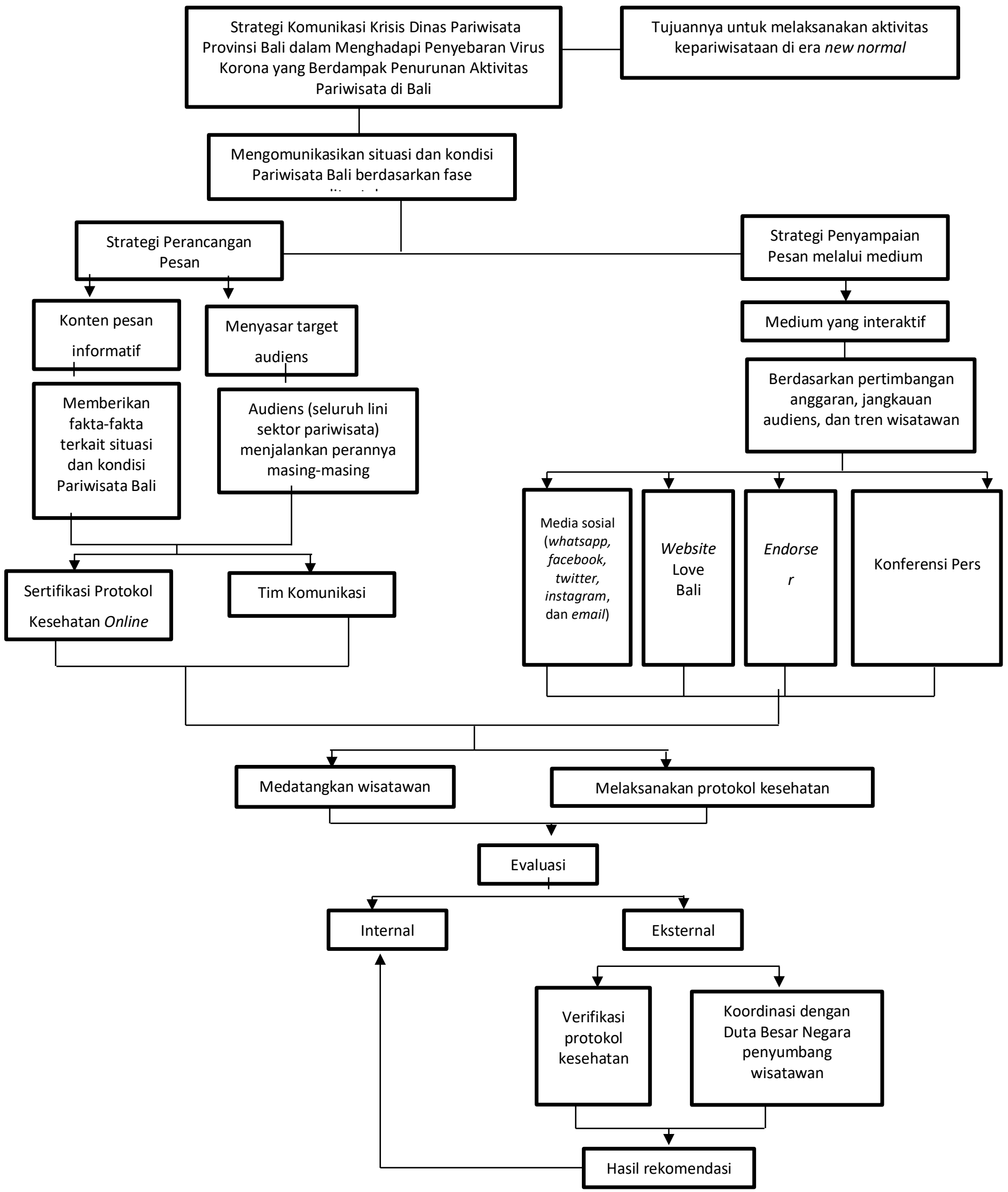

Bagan 1. Strategi Komunikasi Krisis Dinas Pariwisata Provinsi Bali Sumber: Olahan Peneliti, Agustus 2020 
Dalam strategi komunikasi Dinas Pariwisata Provinsi Bali ada beberapa faktor pendukung yang mendukung pelaksanaannya. Faktor pendukungnya antara lain:

a. Media yang berperan proaktif: Peran media baik media konvensional dan media digital dikatakan sangat penting untuk mengomunikasikan dan memperlihatkan keadaan dan kondisi Bali secara faktual

b. Asosiasi pariwisata yang bergerak aktif: Peran asosiasi pariwisata di Bali sangat membantu Dinas Pariwisata dalam menjalankan program kerjanya, terutama dalam hal ini kaitannya dengan menghadapi penyebaran Virus Korona.

c. Peran tokoh adat di Bali: Tokoh adat di Bali sangat penting perannya, karena di Bali tokoh adat sangat dihormati dan selalu dipercaya, sehingga memudahkan pemerintah dalam hal ini Dinas Pariwisata Provinsi Bali untuk menyampaikan informasi sehingga bisa diterima oleh masyarakat.

d. Kesadaran dari masyarakat: Kesadaran masyarakat dikatakan sebagai faktor yang paling berpengaruh dalam upaya mempertahankan sektor pariwisata Bali di tengah penyebaran Virus Korona. Tingkat kesadaran masyarakat Bali dikatakan cukup Baik karena mengingat hampir sebagian besar profesi masyarakat Bali bergantung pada sektor pariwisata.

Dalam strategi komunikasi Dinas Pariwisata Provinsi Bali ada beberapa faktor penghambat yang menghambat pelaksanaannya. Faktor penghambatnya antara lain:

a. Penyebaran berita bohong: Dengan tersebarnya beberapa berita bohong, hal itu sangat menghambat pemerintah: dalam hal ini Dinas Pariwisata Provinsi Bali dalam menjalankan strategi komunikasinya. Berita bohong dapat menyebabkan disinformasi sehingga menimbulkan keresahan di masyarakat.

b. Kurangnya literasi dan informasi di masyarakat: Kurangnya literasi dan informasi menjadi faktor penghambat yang paling berpengaruh, karena dengan ketidaktahuan tersebut mengakibatkan masyarakat salah bertindak.

\section{Simpulan}

Strategi komunikasi krisis yang dilaksanakan Dinas Pariwisata Provinsi Bali dalam mengatasi penyebaran Virus Korona yang berdampak penurunan aktivitas pariwisata di Bali bertujuan untuk melaksanakan aktivitas kepariwisataan pada masa new normal, dengan cara menginformasikan situasi dan kondisi Pariwisata Bali berdasarkan fase yang telah ditentukan. Pada perencanaan pesan, Dinas Pariwisata Provinsi Bali menyajikan konten pesan informatif, yaitu dengan menginformasikan situasi dan kondisi Pariwisata Bali berdasarkan fase yang telah ditentukan. Pesan yang disampaikan juga mengupayakan agar tepat sasaran, agar pesan yang telah disampaikan dapat dilaksanakan dengan teapt. Pada penyampaian pesan melalui media, Dinas Pariwisata Provinsi Bali menggunakan media interaktif, agar pesan informatif yang disampaikan dapat dikonfirmasi oleh audiens sehingga tidak terjadi kesalahpahaman. Dalam menggunakan media, ada beberapa indikator yang digunakan, yaitu anggaran, jangkauan audiens, dan tren wisatawan. 
Pada tahap pelaksanaan, Dinas Pariwisata Provinsi Bali melibatkan seluruh lini sektor pariwisata, seperti hotel, restoran, travel agent, transportasi, objek wisata, dan lainnya dalam pembuatan sertifikasi protokol kesehatan secara online dan pembentukan Tim Komunikasi. Media yang digunakan dalam menyampaikan pesan kepada audiens adalah media sosial, yaitu whatsapp, facebook, twitter, instagram, dan email. Media website yang digunakan adalah Love Bali. Dinas Pariwisata juga memanfaatkan konferensi pers untuk mengklarisikasi berita.

Pada tahap evaluasi, Dinas pariwisata Provinsi Bali melaksanakan evaluasi secara internal dan eksternal. Internal dilakukan dengan cara memeriksa funsgi dari departemen internal dalam membuat program kerja dalam pemulihan pariwisata di masa new normal. Evaluasi eksternal dilakukan dengan cara melaksanakan verifikasi protokol kesehatan kepada seluruh lini sektor pariwisata, hal ini dilaksanakan untuk mengetahui seberapa besar kesiapan pariwisata Bali untuk beroperasi. Dinas Pariwisata juga menjalin koordinasi dengan Duta Besar dari negara penyumbang wisatawan untuk mengetahui situasi dari negara tersebut, sehingga aktivitas kepariwisataan dapat dilaksanakan dengan aman.

Dalam melaksanakan strategi komunikasi krisisnya, Dinas Pariwisata Provinsi Bali memiliki beberapa faktor pendukung, seperti media yang sangat berperan aktif dalam mengomunikasikan dan memperlihatkan keadaan dan kondisi Bali secara faktual. Asosiasi pariwisata di Bali yang berperan aktif sehingga membantu program kerja Dinas Pariwisata Provinsi Bali. Peran tokoh adat untuk membantu Dinas Pariwisata Provinsi Bali untuk menyampaikan pesan ke masyarakat. Kesdaran masyarakat Bali akan pentingnya pariwisata bagi mereka membantu program dari Dinas Pariwisata Provinsi Bali. Sekalipun demikian, terdapat faktor penghambat, seperti adanya penyebaran berita bohong terkait situasi dan keadaan pariwisata Bali dan kurangnya literasi dan informasi.

\section{Daftar Pustaka}

Ahmadi, R. (2014). Metodologi Penelitian Kualitatif. Yogyakarta: Ar-Ruzz Media.

Astawa, P. (2020, August 28). Personal Interview.

Buku Statistik Wisman 2019. (2020, January 31). Diakses dari: https://disparda.baliprov.go.id/ buku-statistikwisman-2019

Bungin, B. (2015). Komunikasi Pariwisata (Tourism Communication) Pemasaran dan Brand Destinasi. Jakarta: Prenanda Media Group.

Cangara, H. (2013). Perencanaan dan Strategi Komunikasi. Jakarta: PT Rajagrafindo Persada.

Kriyantono, R. (2006). Teknik Praktis Riset Komunikasi. Jakarta: Kencana.

Kriyantono, R. (2015). Public Relations, Issue and Crisis Management Pendekatan Critical Public Relations, Etnografi kritis dan Kualitatif. Jakarta: Prenanda Media Group .

Priyatno, Ardi. (2020, March 12). WHO Umumkan Virus Corona Sebagai Pandemi Global. Kompas.com. Diakses dari https://www.kompas.com/

STR / AFP. (2020, January 31). $10 \mathrm{Hal}$ yang Harus Diketahui Soal Virus Corona. CNN Indonesia. Diakses dari https://www.cnnindonesia.com/

Tatang. (2016). Dinamika komunikasi. Bandung: CV. Pustaka Setia. 